\title{
Kapasitas Penyerapan dan Penyimpanan Air pada Berbagai \\ Ukuran Potongan Rumput Laut Gracilaria verrucosa sebagai Bahan Dasar Pupuk Organik
}

\author{
Anik Muji Haryanti, Sri Darmanti, Munifatul Izzati \\ Lab. Biologi Struktur dan Fungsi Tumbuhan Jurusan Biologi Fak. MIPA Undip
}

\begin{abstract}
Abstrak
Gracilaria verrucosa merupakan salah satu dari 555 jenis rumput laut yang ditemukan di perairan Indonesia. Merupakan alga merah yang thalusnya mengandung gel sehingga mempunyai kemampuan mengikat air yang cukup tinggi. Besarnya air yang dapat diserap dan disimpan tergantung dari luas bidang penyerapan. Selain hal tersebut, Gracilaria verrucosa seperti rumput laut umumnya mengandung makro mineral, mikro mineral, protein, karbohidrat dan vitamin A dan C. Karena hal tersebut, maka Gracilaria verrucosa mempunyai potensi yang tinggi untuk diamanfaatkan dalam bidang pertanian khususnya pada lahan dengan partikel tanah yang besar seperti lahan pasir yaitu sebagai bahan penyerap dan penyimpan air sekaligus sebagai sumbur pupuk organik. Penelitian ini bertujuan untuk mengetahui kapasitas penyerapan dan penyimpanan air oleh Gracilaria verrucosa pada berbagai ukuran potongan. Penelitian menggunakan RAL, dengan perlakuan tunggal, terdiri dari 3 taraf perlakuan ukuran potongan yaitu $0,25 \mathrm{~cm}, 0,5 \mathrm{~cm}$ dan $1 \mathrm{~cm}$. masing-masing perlakuan dengan 3 ulangan. Kesimpulannya adalah bahwa ukuran potongan berpengaruh terhadap kapasitas penyerapan dan penyimpanan air, kapasitas penyerapan tertinggi pada potongan $0,25 \times 0,25 \mathrm{~cm}$ dan kapasitas penyimpanan tertinggi pada potongan $1 \times 1 \mathrm{~cm}$.
\end{abstract}

Kata Kunci : Gracilaria verrucosa, rumput laut, pupuk organik

\section{PENDAHULUAN}

Wilayah perairan Indonesia kurang lebih $70 \%$ terdiri dari laut, yang pantainya kaya akan berbagai jenis sumber hayati yang potensial untuk dimanfaatkan sebagai bahan pangan, pupuk organik dan lain-lain. Keadaan ini merupakan salah satu faktor yang dapat menunjang keberhasilan pengembangan komoditas sumber daya hayati laut. Afrianto dan Liviawati (1993) menyatakan bahwa salah satu sumber daya hayati laut yang memiliki potensi kandungan bahan pangan dan bahan farmasi yang cukup potensial dan merupakan komoditi yang bernilai ekonomis karena sangat dibutuhkan oleh manusia serta sering digunakan sebagai bahan baku industri adalah rumput laut atau seaweed.

Menurut Atmadja dkk. (1996), pada perairan Indonesia ditemukan 555 jenis rumput laut, dari jumlah tersebut 21 jenis diantaranya dapat menghasilkan agar-agar. Jenis-jenis ini antara lain : Gracilaria sp, Gelidium sp, Gelidellia sp dan Gelidiopsis sp. Jenis Gracilaria yang sering dijumpai di Indonesia adalah $G$. lichenoides, $G$. gigas dan G. verrucosa.
Secara morfologi rumput laut tidak dapat dibedakan antara akar, batang dan daun. Berupa thalus dengan bentuk bermacam-macam. Thalus ini ada yang uniseluler dan multiseluler. Sifat substansi thalus beranekaragam, ada yang lunak seperti gelatin (gelatinous), kertas diliputi atau mengandung zat kapur (calcareous), lunak seperti tulang rawan (cartilagenous), berserabut (spongious) dan sebagainya (Aslan, 1995). Karena sifat substansinya tersebut, rumput laut memiliki kemampuan penyerapan dan penyimpanan air yang berbeda dengan tanaman lain yang tumbuh di darat. Misalnya pada Gracilaria, rumput laut ini merupakan salah satu jenis alga merah yang banyak mengandung gel dimana gel ini memiliki kemampuan mengikat air yang cukup tinggi. Karena mengandung gel, penyerapan air tergantung pada luas permukaan rumput laut sehingga ukuran potongan yang berbeda akan berpengaruh pada tingkat penyerapan dan peyimpanan airnya.

Karena memiliki kemampuan menyerap dan menyimpan air menjadikan rumput laut sangat potensial digunakan pada bidang pertanian, terutama pada lahan dengan ukuran partikel tanah 
yang cukup besar seperti pada tanah pasair. Tanah yang terdiri atas partikel besar kurang dapat menahan air. Air yang ada dalam tanah akan berinfiltrasi, bergerak ke bawah melalui rongga tanah, akibatnya tanah kekurangan air. Kondisi ini apabila terus menerus dapat mematikan tanaman (Dwidjoseputro, 1978).

Selain kemampuannya menyerap dan menyimpan air, rumput laut mengandung unsur makromineral dan unsur mikromineral yang dibutuhkan oleh tanaman sehingga sangat baik untuk dijadikan bahan pupuk organik. Kandungan rumput laut umumnya adalah mineral esensial (besi, iodin, aluminum, mangan, calsium, nitrogen dapat larut, phosphor, sulfur, chlor. silicon, rubidium, strontium, barium, titanium, cobalt, boron, copper, kalium, dan unsur-unsur lainnya yang dapat dilacak), protein, tepung, gula dan vitamin A, C dan D (http://www.dkp.go.id).

Dari latar belakang diatas maka timbul permasalahan yaitu bagaimanakah kapasitas penyerapan dan penyimpanan air Gracilaria verrucosa pada berbagai ukuran potongan yang berbeda. Dari penelitian ini diharapkan dapat diketahui ukuran potongan rumput laut Gracilaria verrucosa yang paling baik digunakan untuk meningkatkan ketersediaan air pada tanah pasir sekaligus sebagai pupuk organik.

\section{BAHAN DAN METODE}

\section{Alat dan Bahan}

Timbangan, ember, pisau, oven, toples, saringan, penggaris, dan kertas koran, rumput laut Gracilaria verrucosa sebanyak $1 \frac{1}{2} \mathrm{~kg}$ dan air.

\section{Cara Kerja}

a. Persiapan rumput laut.

Persiapan diawali dengan penyediaan bahan yaitu rumput laut Gracilaria verrucosa. Rumput laut direndam dalam air selama kurang lebih 3 hari. Tujuan dari perendaman ini adalah agar rumput laut menjadi lunak dan segar kembali.

b. Perlakuan

Dibuat potongan sesuai dengan perlakuan. Masing-masing perlakuan digunakan rumput laut sebanyak $1 / 2 \mathrm{~kg}$, yaitu :

P1 : Dipotong ukuran $0,25 \times 0,25 \mathrm{~cm}$

P2 : Dipotong ukuran $0,5 \times 0,5 \mathrm{~cm}$
P3 : Dipotong ukuran $1 \times 1 \mathrm{~cm}$

c. Pengeringan

1. Dari 3 macam perlakuan tersebut kemudian dikeringkan dibawah sinar matahari selama 2-3 hari

2. Dikeringkan lagi dalam oven dengan suhu $50^{\circ} \mathrm{C}$ hingga mencapai berat konstan (ditimbang setiap 1 hari sekali)

3. Dari ketiga perlakuan (P1, P2, dan P3), masing-masing diambil rumput laut dengan berat yang sama yaitu $5 \mathrm{~g}$ dan dibuat 3 ulangan.

d. Pengukuran parameter.

1. Dari 3 macam perlakuan, masing-masing disiram dengan air secara langsung, kemudian ditimbang untuk mengetahui kapasitas penyerapan air sesaat

2. Setelah menimbang kapasitas penyerapan air sesaat, rumput laut direndam dalam air dengan volume yang sama dan ditimbang tiap 45 menit untuk mengetahui laju penyerapan airnya

3. Dilakukan penimbangan setelah 2 hari direndam untuk mengetahui kapasitas penyerapan airnya

4. Dibiarkan di udara terbuka dan ditimbang lagi tiap 45 menit untuk mengetahui kemampuan menyimpan air

5. Dibuat tabel penimbangan tiap 45 menit untuk mengetahui banyaknya air yang tersimpan

6. Dihitung kapasitas penyerapan air sesaat, kapasitas penyerapan air setelah direndam selama 2 hari dan kapasitas penyimpanan air. Setelah itu dibuat grafik

3. Analisis Data

Data yang diambil dalam penelitian ini adalah berat basah sebagai parameter penyerapan dan penyimpanan air. Analisis kapasitas penyerapan dan penyimpanan air menggunakan perhitungan dengan rumus :

$$
\mathrm{Ka}=\frac{\mathrm{B}_{1}-\mathrm{B}_{2}-}{\mathrm{B}_{2}} \times 100 \%
$$

Keterangan :

$\mathrm{Ka}=$ Kapasitas penyerapan ataupun

penyimpanan air

$\mathrm{B}_{1}=$ Berat setelah perlakuan $(\mathrm{g})$

$\mathrm{B}_{2}=$ Berat sebelum perlakuan $(\mathrm{g})$ 
Data kapasitas penyerapan dan penyimpanan air kemudian dianalisa dengan Analisis varian untuk mengetahui pengaruh ukuran potongan rumput laut terhadap kapasitas penyerapan dan penyimpanan air, dan dilanjutkan dengan uji Duncans pada taraf kepercayaan $95 \%$.

\section{HASIL DAN PEMBAHASAN}

Dari hasil analisis terhadap data didapatkan hasil sebagai berikut :

1. Kapasitas Penyerapan Air

1.1. Kapasitas Penyerapan Air Sesaat

Hasil penghitungan kapasitas penyerapan air Gracilaria verrucosa sesaat setelah disiram air ditunjukkan dalam Tabel 1.

\begin{tabular}{cccc}
\hline $\begin{array}{c}\text { Potongan } \\
\text { Ulangan }\end{array}$ & $\begin{array}{c}0.25 \mathrm{~cm} \\
(\%)\end{array}$ & $\begin{array}{c}0.5 \mathrm{~cm} \\
(\%)\end{array}$ & $\begin{array}{c}1 \mathrm{~cm} \\
(\%)\end{array}$ \\
\hline 1 & 458 & 430 & 366 \\
2 & 412 & 418 & 390 \\
3 & 454 & 378 & 384 \\
Rata-rata (\%) & $441.3^{\mathrm{a}}$ & $408.7^{\mathrm{ab}}$ & $380^{\mathrm{b}}$ \\
\hline
\end{tabular}

Keterangan : Angka-angka yang diikuti oleh huruf yang berbeda menunjukkan hasil yang berbeda nyata pada uji Duncan

Hasil Analisis menunjukkan bahwa ukuran potongan rumput laut yang berbeda memiliki pengaruh terhadap kapasitas penyerapan sesaat. Uji Duncan menunjukkan bahwa potongan 0.25 $\mathrm{cm}$ berbeda nyata dengan potongan $1 \mathrm{~cm}$ sedangkan potongan $0.5 \mathrm{~cm}$ berbeda tidak nyata. Dapat dikatakan bahwa potongan $0.25 \mathrm{~cm}$ dan potongan $1 \mathrm{~cm}$ berpengaruh secara nyata terhadap kapasitas penyerapan sesaat Gracilaria verrucosa sedangkan untuk potongan $0.5 \mathrm{~cm}$ berpengaruh tetapi tidak nyata dimana ukuran potongan yang terkecil memiliki kapasitas penyerapan sesaat yang paling tinggi.

1.2. Kapasitas Penyerapan Air Setelah Perendaman Hasil penghitungan kapasitas penyerapan air Gracilaria verrucosa setelah perendaman selama 2 hari dalam air ditunjukkan dalam tabel 2 .
Tabel 2. Kapasitas penyerapan air Gracilaria verrucosa setelah direndam air selama 2 hari

\begin{tabular}{cccc}
\hline $\begin{array}{c}\text { Potongan } \\
\text { Ulangan }\end{array}$ & $\begin{array}{c}0.25 \mathrm{~cm} \\
(\%)\end{array}$ & $\begin{array}{c}0.5 \mathrm{~cm} \\
(\%)\end{array}$ & $1 \mathrm{~cm} \mathrm{( \% )}$ \\
\hline 1 & 1138 & 1024 & 954 \\
2 & 1170 & 1136 & 1030 \\
3 & 1152 & 1066 & 1126 \\
$\begin{array}{c}\text { Rata-rata } \\
(\%)\end{array}$ & $1153.3^{\mathrm{a}}$ & $1075.3^{\mathrm{ab}}$ & $1020^{\mathrm{b}}$ \\
& & & \\
\hline
\end{tabular}

Keterangan : Angka-angka yang diikuti oleh huruf yang berbeda menunjukkan hasil yang berbeda nyata pada uji Duncan

Seperti halnya kapasitas penyerapan sesaat, untuk kapasitas penyerapan setelah perendaman 2 hari dalam air, potongan $0.25 \mathrm{~cm}$ memiliki kapasitas penyerapan yang tertinggi yaitu dengan nilai rata-rata $1153.3 \%$ diikuti potongan $0.5 \mathrm{~cm}$ dengan nilai rata-rata $1075.3 \%$ dan potongan $1 \mathrm{~cm}$ dengan nilai rata-rata $1020 \%$. Hal ini dapat dibuktikan dengan Analisis Varian yang menunjukkan bahwa ukuran potongan rumput laut yang berbeda memiliki pengaruh terhadap kapasitas penyerapan air dan untuk Uji Duncan memperlihatkan bahwa potongan $0.25 \mathrm{~cm}$ dan potongan $1 \mathrm{~cm}$ berbeda secara nyata kapasitas penyerapan airnya tetapi untuk potongan $0.5 \mathrm{~cm}$ tidak berbeda nyata. Hal ini menunjukkan bahwa ukuran potongan berpengaruh terhadap kapasitas penyerapan air Gracilaria verrucosa. Ukuran potongan yang paling kecil memiliki kapasitas penyerapan yang lebih tinggi. Hal ini disebabkan karena dengan ukuran potongan yang kecil maka luas permukaan akan lebih besar sehingga air yang diserap lebih banyak. Dengan begitu kapasitas penyerapan airnya akan lebih besar. Sebagaimana dikemukakan oleh Islami dan Utomo (1995) bahwa dengan peningkatan luas permukaan maka menyebabkan absorbsi air berjalan lebih baik. Penyerapan air sendiri yang terjadi pada Gracilaria verrucosa disebabkan karena adanya difusi molekul-molekul air atau disebut osmosis. Sebagaimana dikemukakan oleh Dwidjoseputro (1978) bahwa arah gerakan difusi yaitu ke tempat yang kekurangan molekul, atau ke tempat yang berkonsentrasi rendah. Tekanan yang menyebabkan molekul- molekul menyebar ke seluruh jurusan disebut dengan tekanan difusi dan 
bila suatu molekul berdifusi melalui suatu poripori maka disebut dengan osmosis.

\section{Laju Penyerapan Air}

Hasil penghitungan rata-rata kapasitas penyerapan air Gracilaria verrucosa tiap 45 menit setelah direndam air ditunjukkan dalam Tabel 3.

Tabel .3. Rerata kapasitas penyerapan air Gracilaria verrucosa tiap 45 menit setelah direndam dalam air

\begin{tabular}{lcccc}
\hline $\begin{array}{l}\text { Waktu } \\
\text { (mnt) }\end{array}$ & $\begin{array}{c}45 \\
(\%)\end{array}$ & $\begin{array}{c}90 \\
(\%)\end{array}$ & $\begin{array}{c}135 \\
(\%)\end{array}$ & $\begin{array}{c}180 \\
(\%)\end{array}$ \\
\hline Potongan & & & & \\
\hline $0.25 \mathrm{~cm}$ & & & & 1010. \\
& 866.7 & 914 & 970.7 & 7 \\
$0.5 \mathrm{~cm}$ & 778.7 & 859.3 & 944 & 962.7 \\
$1 \mathrm{~cm}$ & 771.3 & 830 & 909.3 & 961.3 \\
\hline
\end{tabular}

bahwa terjadi peningkatan penyerapan air tiap 45 menit dimana ukuran potongan $0.25 \mathrm{~cm}$ memiliki kapasitas penyerapan paling tinggi diikuti dengan ukuran potongan $0.5 \mathrm{~cm}$ dan ukuran potongan 1 $\mathrm{cm}$. Laju peningkatan kapasitas penyerapan air dapat ditunjukkan pada Gambar 3.

Berdasarkan tabel diatas menunjukkan bahwa terjadi peningkatan penyerapan air tiap 45 menit dimana ukuran potongan $0.25 \mathrm{~cm}$ memiliki kapasitas penyerapan paling tinggi diikuti dengan ukuran potongan $0.5 \mathrm{~cm}$ dan ukuran potongan 1 $\mathrm{cm}$. Laju peningkatan kapasitas penyerapan air dapat ditunjukkan pada Gambar 3.



Gambar 1. Grafik laju kapasitas penyerapan air Gracilaria verrucosa setelah direndam dalam air
Dari grafik diatas dapat dikatakan bahwa pada tiap-tiap perlakuan memiliki laju kapasitas penyerapan yang berbeda-beda. Pada potongan $0.25 \mathrm{~cm}$ terjadi peningkatan penyerapan air yang terjadi sedikit demi sedikit tiap 45 menitnya. Pada potongan $0.5 \mathrm{~cm}$ terjadi peningkatan penyerapan air yang cukup tinggi pada menit ke 45 hingga menit ke 135 tetapi mengalami penurunan pada menit ke 180. Sedangkan pada potongan $1 \mathrm{~cm}$, penyerapan airnya meningkat terus mulai dari 45 menit pertama hingga 180 menit.

\section{Kapasitas Penyimpanan Air}

Hasil penghitungan kapasitas penyimpanan air Gracilaria verrucosa pada penimbangan terakhir yaitu pada menit ke 225 setelah dibiarkan diudara terbuka dan rata-rata kapasitas penyimpanan air ditunjukkan dalam Tabel 4 dan 5.

Tabel 4. Kapasitas penyimpanan air Gracilaria verrucosa pada menit ke 225

\begin{tabular}{cccc}
\hline $\begin{array}{c}\text { Potongan } \\
\text { Ulangan }\end{array}$ & $\begin{array}{c}0.25 \\
\mathrm{~cm}(\%)\end{array}$ & $\begin{array}{c}0.5 \mathrm{~cm} \\
(\%)\end{array}$ & $1 \mathrm{~cm}(\%)$ \\
\hline 1 & 796 & 774 & 788 \\
2 & 804 & 786 & 760 \\
3 & 796 & 790 & 782 \\
Rata-rata & $798.7^{\mathrm{a}}$ & $783.3^{\mathrm{ab}}$ & $776.7^{\mathrm{b}}$
\end{tabular}

(\%)

Keterangan : Angka-angka yang diikuti oleh tanda bintang menunjukkan hasil yang berbeda nyata pada uji Duncan

4. Rerata kapasitas penyimpanan air Gracilaria verrucosa tiap 45 menit setelah dibiarkan diudara terbuka

Keterangan : Angka-angka yang diikuti oleh tanda bintang menunjukkan hasil yang berbeda nyata pada uji Duncan 
Tabel 5. Rerata kapasitas penyimpanan air Gracilaria verrucosa tiap 45 menit setelah dibiarkan diudara terbuka

\begin{tabular}{lccccc}
\hline Waktu & 45 & 90 & 135 & 180 & 225 \\
$(\mathrm{mnt})$ & $(\%)$ & $(\%)$ & $(\%)$ & $(\%)$ & $(\%)$ \\
Potongan & & & & & \\
\hline $0.25 \mathrm{~cm}$ & 967.3 & 904.7 & 855.3 & 823.3 & 798.7 \\
$0.5 \mathrm{~cm}$ & 946 & 898 & 836 & 802.7 & 783.3 \\
$1 \mathrm{~cm}$ & 927.3 & 884.7 & 826 & 795.3 & 776.7 \\
\hline
\end{tabular}

Dari tabel diatas menunjukkan bahwa terjadi penurunan kapasitas penyimpanan air tiap 45 menit pada masing-masing perlakuan. Laju penurunan kapasitas penyimpanan air dapat ditunjukkan pada Gambar 2.

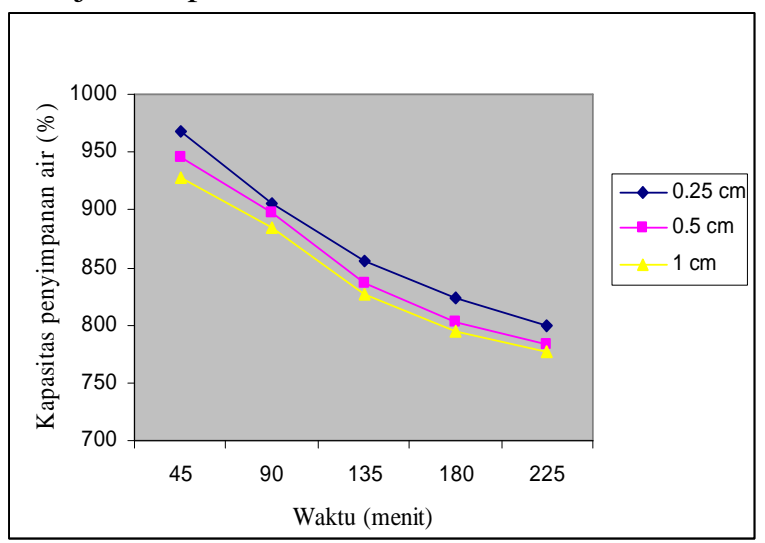

Gambar 2. Grafik kapasitas penyimpanan air Gracilaria verrucosa setelah dibiarkan di udara terbuka

Kapasitas penyimpanan air Gracilaria verrucosa mengalami penurunan tiap 45 menit setelah dibiarkan di udara terbuka. Penurunan kapasitas penyimpanan air pada tiap perlakuan apabila dilihat rata-ratanya kapasitas penyimpanan air yang paling baik adalah pada potongan $1 \mathrm{~cm}$. Ini dapat diketahui dari tingkat penurunan kapasitas penyimpanan air tiap 45 menit pada potongan $1 \mathrm{~cm}$ yang terjadi sedikit demi sedikit yaitu dari $927.3 \%$ menjadi $776.7 \%$ dengan nilai penurunan kapasitas yang paling kecil diantara perlakuan yang lain. Karena nilai penurunannya paling kecil, maka air yang tersimpan lebih banyak sehingga kemampuan menyimpan airnya lebih besar. Dapat dikatakan bahwa pada potongan $1 \mathrm{~cm}$ kapasitas penyimpanan airnya lebih baik dibandingkan dengan potongan $0.5 \mathrm{~cm}$ dan $1 \mathrm{~cm}$. Dari Analisis Varian dengan menggunakan kapasitas penyimpanan terakhir yaitu pada menit ke 225 memperlihatkan bahwa ukuran potongan rumput laut yang berbeda memiliki pengaruh terhadap kapasitas penyimpanan air dan untuk Uji Duncan mempelihatkan bahwa potongan $1 \mathrm{~cm}$ berbeda secara nyata kapasitas penyimpanan airnya dengan potongan $0.25 \mathrm{~cm}$ tetapi untuk potongan $0.5 \mathrm{~cm}$ tidak berbeda nyata. Dapat dikatakan bahwa ukuran potongan berpengaruh terhadap penyimpanan air Gracilaria verrucosa. Potongan $1 \mathrm{~cm}$ memiliki tingkat penurunan kapasitas penyimpanan air yang lebih kecil dibandingkan perlakuan yang lain sehingga air yang tersimpan lebih banyak. Terjadinya penurunan kapasitas penyimpanan air disebabkan karena penurunan berat basah Gracilaria verrucosa. Penurunan berat basah ini terjadi karena air yang tersimpan dalam Gracilaria mengalami penguapan (transpirasi) setelah dibiarkan di udara terbuka. Sebagaimana dikemukakan oleh Islami dan Utomo (1995) bahwa sebagian besar air yang diabsorbsi oleh tanaman dikeluarkan lagi ke atmosfer lewat proses transpirasi. Dengan ukuran potongan yang lebih besar maka luas permukaan lebih kecil sehingga kemampuan transpirasi lebih rendah. Dengan kemampuan transpirasi yang rendah maka air yang tersimpan lebih banyak sehingga kapasitas penyimpanan airnya juga lebih baik.

Berkaitan dengan pemanfaatannya sebagai bahan pupuk organik, Gracilaria verrucosa sangat potensial karena substansinya yang mengandung gel sehingga dapat menyerap dan menyimpan air. Selain itu juga mengandung unsur makromineral dan unsur mikromineral yang dibutuhkan oleh tanaman. Kandungan rumput laut umumnya adalah mineral esensial (besi, iodin, aluminum, mangan, calsium, nitrogen dapat larut, phosphor, sulfur, chlor. silicon, rubidium, strontium, barium, titanium, cobalt, boron, copper, kalium, dan unsurunsur lainnya yang dapat dilacak), protein, tepung, gula dan vitamin A, C dan D (http://www.dkp.go.id). Dengan kemampuannya menyerap dan menyimpan air, maka akan menambah kelembaban pupuk yang akan membantu meningkatkan kelembaban tanah sebagai media tumbuh tanaman. Disamping itu, 
dengan keadaan tanah yang lembab maka dapat meningkatkan pertumbuahan mikroorganisme tanah kaitannya dengan penyediaan unsur hara bagi tanaman.

\section{KESIMPULAN}

Dari hasil penelitian ini dapat diambil kesimpulan sabagai berikut :

1. Ukuran potongan Gracilaria verrucosa yang berbeda berpengaruh terhadap kapasitas penyerapan dan penyimpanan airnya

2. Kapasitas penyerapan air yang paling tinggi terdapat pada perlakuan ukuran potongan $0.25 \mathrm{~cm}$

3. Kapasitas penyimpanan air yang paling tinggi terdapat pada perlakuan ukuran potongan $1 \mathrm{~cm}$

\section{DAFTAR PUSTAKA}

Afrianto, E. dan Liviawati, E. 1993. Budidaya Rumput Laut dan Cara Pengolahannya. PT Bhratara Niaga Media, Jakarta.

Aslan, L. M. 1995. Budidaya Rumput Laut. Kanisius, Yogyakarta.

Atmadja, W.S., Sulistijo, Kadi, A., Sahari, R. 1996. Pengenalan Jenis Rumput Laut di Indonesia. P30 LIPI, Jakarta.

Anggadirejo, J. 1995. Gracilaria spp. Resources in Indonesia Seminar Paper : IV, Management of Natural Resource of Agrophyta National Seaweed
Research. Agency for Assesment and Aplication of Technology, Jakarta.

Bidwell, R.G.S. 1979. Plant Physiology. Mc Millan Co. Inc., New York.

Dawes, C.J. 1981. Marine Botany. University of South Florida, USA.

Dwidjoseputro, D. 1978. Pengantar Fisiologi Tumbuhan. PT Gramedia, Jakarta.

Hehanussa, P.E. 1982. Aspek Biologi dalam Pengelolaan Wilayah Pesisir. Journal of The Indonesia Asosiation of Geologist Vol IX/II/1992.

Islami, T. dan Utomo, W.H. 1995. Hubungan Tanah, Air dan Tanaman. IKIP Semarang Press, Semarang.

Salishbury, F. B. dan Ross, C.W. 1990. Fisiologi Tumbuhan III. ITB Press, Bandung.

Sitompul, S.M. dan Guritno, B. 1995. Analisis Pertumbuhan Tanaman. UGM Press. Yogyakarta.

Soegiarto, A., Sulistijo, Atmadja, W.S., Mubarak, H. 1978. Rumput Laut (Algae) Manfaat, Potensi dan Usaha Budidayanya. LON-LIPI, Jakarta.

Sadhori, S.N. 1992. Budidaya Rumput Laut. Balai Pustaka, Jakarta.

http://www.deptan.go.

http://www.worldagroforestry.org.

http://www.ibss.iuf.net.

http://www.dkp.go.id. 